\title{
The Role of Sociopolitical Attitudes and Civic Education in the Civic Engagement of Black Youth
}

\author{
Elan C. Hope \\ University of Chicago
}

\author{
Robert J. Jagers \\ University of Michigan
}

Civic engagement is important for individual and community well-being. In the current study, we use survey data from a nationally representative sample to examine how sociopolitical attitudes, such as political cynicism, perceptions of institutional discrimination, and political efficacy, along with civic education relate to civic engagement among 593 Black youth, ages 15-25. We found perceived institutional discrimination, political efficacy, and civic education were associated with civic engagement, while political cynicism was not. There is evidence to suggest civic education may strengthen the association between perceived institutional discrimination and civic engagement. The present findings contribute to our understanding of how acknowledging systemic inequity promotes civic engagement among Black youth. Findings are discussed in terms of study limitations and future research directions.

It is well established in the research literature that civic engagement is an essential component of positive development for all youth (Lerner, 2004; Yates \& Youniss, 1996), and in particular minority youth (Christens, 2012; Ginwright, 2010a). Community service, civic activism, civic participation, and political participation are all forms of civic engagement that have been shown to have positive impacts among young people (Checkoway, Allison, \& Montoya, 2005; McGuire \& Gamble, 2006; Sherrod, Torney-Puerta, \& Flanagan, 2010; Yates \& Youniss, 1996). Civic engagement is positively related to knowledge of political systems, prosocial behavior, social responsibility, and future civic engagement, such as adult volunteerism and future voting behavior (Hart, Donnelly, Youniss, \& Atkins, 2007; Hart \& Gullan, 2010; Reinders \& Youniss, 2006; Schmid, 2012). In addition to the benefits of civic engagement for youth, there are also community benefits, because youth-led activities often result in projects and policy reforms to improve quality of life in some communities (Ginwright, 2010b; Lerner, 2004).

\section{CIVIC ENGAGEMENT AND BLACK YOUTH}

In this article, we seek to understand how sociopolitical attitudes and civic education relate to civic engagement among Black youth. The existing research literature offers a mixed picture of civic

Requests for reprints should be sent to Elan C. Hope, Department of Comparative Human Development, University of Chicago, 5730 S. Woodland Avenue, Chicago, Illinois 60637.

E-mail: elanhope@uchicago.edu engagement in this population. On one hand, scholars have noted a civic achievement gap, where Black youth report lower levels of civic knowledge, political skills, positive civic and political attitudes, and traditional forms of political participation (e.g., voting, contacting elected officials) than White youth (Levinson, 2007; National Center for Education Statistics [NCES] 2011). The American Political Science Association (APSA, 2004) highlighted growing disparities in political participation across racial, socioeconomic, and generational lines, with older, more wealthy Whites being the most politically active. On the other hand, a recent report indicates that compared with Whites, Blacks had higher levels of voter turnout in recent national elections (File, 2013). Further, research suggests that skepticism about traditional government policies and practices prompts some Black youth to engage in alternative social change strategies such as participating in youth-led social justice movements, providing family financial assistance, community service through religious organizations, and participating in politically motivated cultural and artistic expression through poetry and hip-hop (Ginwright, 2010a; Smetana \& Metzger, 2005; Watts \& Flanagan, 2007).

Given the individual and collective benefits of engaged citizenship, it is important to understand factors that inhibit or facilitate civic engagement among Black youth. Sustained civic effort may be a viable strategy to address persistent racial gaps

(C) 2014 The Authors

Journal of Research on Adolescence (C) 2014 Society for Research on Adolescence DOI: $10.1111 /$ jora. 12117 
experienced in health, education, social and economic outcomes among Blacks compared with other racial or ethnic groups (Sellers, Bonham, Neighbors, \& Amell, 2006; White-Johnson, 2012). Watts, Williams, and Jagers (2003) and Watts and Guessous (2006) proposed a model of sociopolitical development (SPD) that provides a useful heuristic for conceptualizing our initial investigation in this area. The SPD model extends the psychological study of civic engagement by considering contextual and individual factors that influence the ways that marginalized groups, such as Blacks, understand and become involved in political and civic action for societal change. Civic engagement is supported by the sociopolitical attitudes of critical social analysis and political efficacy, which are influenced by early socialization experiences, such as formal and informal civic education (see Figure 1).

\section{THE ROLE OF CRITICAL SOCIAL ANALYSIS}

In the 1970s, while working with disenfranchised peoples in Brazil, Paolo Freire developed the idea of critical consciousness: to redress systemic inequities, people must first understand deeply the nature of mechanisms that work to establish and maintain such asymmetric social relations (Freire, 2005). Scholars contend that this same fundamental principal holds true for marginalized groups today, such as Black youth (Watts, Diemer, \& Voight, 2011). Critical analysis of the sociopolitical environment can offer an understanding of the nature, impacts, and possible responses to limited political, economic, and social access and resources (Watts \& Guessous, 2006). Critical social analysis relates to civic engagement, especially for adolescents and young adults, because this developmental period offers increased opportunities for young people to expand and refine their social and political

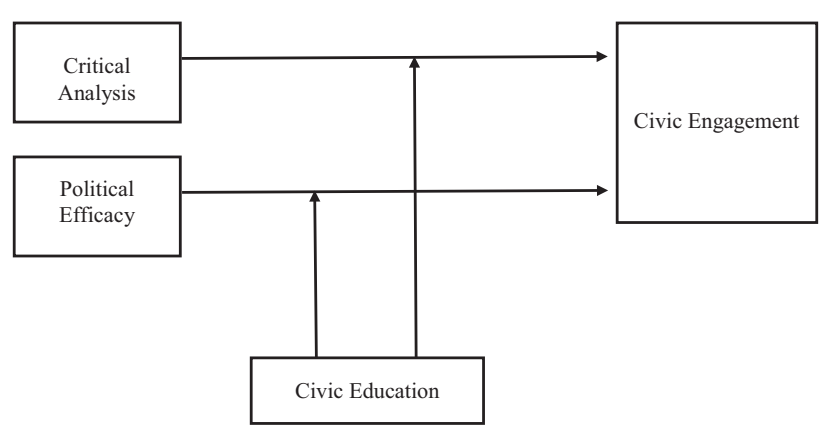

FIGURE 1 Conceptual model. points of view and actions (Finlay, Wray-Lake, \& Flanagan, 2010; Slater, Fain, \& Rossatto, 2002).

The legacy of racialized oppression in the United States means that issues of race are likely to inform the ways in which Black youth understand their current social, economic, and political circumstances. Racial discrimination can occur interpersonally but is also embedded within institutions and social systems that have created and maintain current social norms (Bonilla-Silva, 1997). Previous research has found that adolescents not only recognize such institutional race-based discrimination (Rosenbloom \& Way, 2004), but these perceptions of institutional discrimination are related to lower life satisfaction and self-esteem (Seaton \& Yip, 2009). Even still, scholars suggest, "adolescents who are aware of racism and the history of racial oppression are better prepared to cope in a racist environment" (Stevenson, McNeil, Herrero-Taylor, \& Davis, 2005).

Research supports this assumption. For instance, research suggests that personal and historical knowledge of racial discrimination can cause Black students to call into question American ideals such as liberty and justice; however, it can also lead to an understanding of ways that engaged citizenship can be used to address these inequities (Rubin, 2007). Indeed, Black young adults who experience racial discrimination are also more involved in civic and political activities and endorse the involvement of Blacks in local communities and broader politics (White-Johnson, 2012). Consistent with this, Flanagan and Gallay (2008) report that ethnic minority students were less trusting than Whites of elected officials, government response to ordinary people, and the American promise of fairness and equity. Higher levels of government trust were associated with commitment to participatory citizenship (e.g., voting), while lower levels of government trust was associated with justice-oriented political action. This finding highlights ways that interpretations of government trustworthiness differentially impact civic engagement among youth. In the current study, we take up these questions further through an investigation of whether sociopolitical attitudes, such as political cynicism and perceptions of institutional discrimination, are associated with civic engagement among Black youth.

\section{POLITICAL EFFICACY AND CIVIC ENGAGEMENT}

Along with the direct effect of critical analysis, the SPD model posits that political efficacy may impact 
civic engagement (Watts \& Flanagan, 2007; Watts \& Guessous, 2006). Political efficacy refers to an individual's belief in one's own capacity to use knowledge and skills to act socially and politically; the personal belief that one has the capacity to bring about community change through one's actions (Beaumont, 2010). The fundamental assumption of this component of SPD is that people take action when they believe that their efforts can make a difference. Some empirical work has been found to support this theoretical assumption. Rubin (2007) found a link between perceived discrimination and increased efficacy for future civic behavior. Diemer and $\mathrm{Li}$ (2011) also found that perceived ability to impact social and political change was related to voting behavior among marginalized youth. Further, self-efficacy to promote justice was found to moderate the relationship between just world beliefs and prosocial behavior (Mohiyeddini \& Montada, 1998). Additionally, Watts and Guessous (2006) found that for minority youth experiences of agency in previous community or political projects moderated the relationships between just world beliefs and commitment to future civic activities, but did not predict recent past civic behaviors. Given these findings, we will examine the direct relationship between political efficacy and civic engagement.

\section{CIVIC EDUCATION AS A SOCIALIZING EXPERIENCE}

Schools can be important contexts to prepare the next generation with an understanding of the democratic principles and practices needed to maintain American society and to address concerns of equal rights and access for all people. The social studies curricula are a primary means for schools to achieve this socializing function. According to the Center for Information and Research on Civic Learning and Engagement, forty states require students take at least one American government or civic course prior to high school graduation (Godsay, Henderson, Levine, \& Littenberg-Tobias, 2012). Unfortunately, national data indicate that youth of color receive less exposure to schoolbased civic education (Kahne and Middaugh, 2008). This limited exposure may be a key contributor to the gaps in civic knowledge, attitudes, and participation that favors White and wealthier students compared to youth of color and lower income students (Levinson, 2012; NCES, 2011). Moreover, for those who do receive school-based civic education, this knowledge of American government and traditional civic expectations may help enhance political efficacy and expand critical analysis in support of civic engagement. In the present study, we examine the assumption that the primary contribution of schools as socializing agents to civic engagement is through critical analysis. That is, civic education is thought to foster a critical analysis of social systems and other institutions that then lead to civic behavior. However, it also seems plausible that civic education can impact civic behaviors by increasing political efficacy; as such, we examine this possibility. While curricular content of civic education is ideal, the literature suggests that whether or not students receive civic instruction is a useful initial representation of participant's civics learning opportunity (Dassonneville, Quintelier, Hooghe, \& Claes, 2012).

\section{STUDY AIMS}

Taken together, we considered the sociopolitical attitudes of critical analysis and political efficacy and civic education as predictors of civic engagement among Black youth. Based on previous work, we predicted that critical social analysis is related to civic engagement such that political cynicism would be negatively related to civic engagement while perceptions of institutional discrimination would be positively related to civic engagement. Additionally, we predicted that political efficacy and civic education is positively associated with civic engagement. Based on the theoretical tenants of SPD and some empirical findings (Watts \& Guessous, 2006), we also examined the moderation effect of civic education on the relation between critical analysis and civic engagement, as well as the relation between political efficacy and civic engagement. We expected that civic education would strengthen the relationship between critical analysis and civic engagement, and between political efficacy and civic engagement. This study contributes to the current literature by specifically examining aspects of critical analysis as unique contributors to civic engagement processes among Black youth. This initial study brings together previous theoretical and empirical scholarship and simultaneously points to future directions for our work in this area of inquiry.

\section{METHOD}

In this study, we used data from the Black Youth Project - Youth Culture Survey (BYP) (Cohen, 2005). The goal of BYP is to explore political 
actions and attitudes among Black youth. Our data come from the Youth Culture survey component: a 45-min national telephone survey of youth, ages 15-25. Participants were identified using a random digit dial (RDD) with standard nationally representative techniques as well as an oversample of Hispanic and Black youth and youth in Chicago, where the primary investigator was conducting additional research associated with this study. After households were identified, eligibility was determined by the presence of a youth between the ages of 15 and 25. Data was collected between July and November 2006 for a total of 1,590 Black, Latino, and White survey respondents. Participants were eligible for inclusion in the current study if they self-identified as being Black or African American. For further information regarding methodology used in the BYP please visit the project website at www.blackyouthproject.com.

\section{Participants}

Participants in this study were 634 Black youth ages $15-25$ years old $(M=19.2, S D=3.12)$. Slightly more than half of the sample was female $(54.8 \%)$. A majority of the participants reported being currently enrolled in secondary school or postsecondary education $(72.3 \%)$. On average, both mothers and fathers of the participants completed high school and had some postsecondary education through college or vocational schooling. The mean household income was between \$20,000 and $\$ 29,000$. For all analyses in this study, we used a subsample of participants who had complete data for all study variables $(n=593,6.5 \%$ missing $)$. The participants with complete data did not differ from the participants with missing data by gender $\chi^{2}(1$, $N=635)=2.59, p=.11$, age $t(632)=.82, p=.41$, maternal education level $t(632)=-.07, p=.95$, or school attendance $\chi^{2}(1, N=635)=.71, p=.40$.

\section{Measures}

Political cynicism. One measure of critical social analysis assessed youth perceptions of government responsiveness and fairness in the United States. These four items were measured on a 4-point scale ranging from 1 (strongly agree) to 4 (strongly disagree). Items include, "The leaders in government care very little about people like me" and "The government is pretty much run by a few big interests looking out for themselves and their friends." All items were reverse coded such that higher response indicates stronger feelings of political cynicism. Internal reliability for the political cynicism items was moderate $(\alpha=.59)$.

Perceived institutional discrimination. Another measure of critical social analysis assessed youth beliefs regarding structural causes for racial discrimination in the United States. This scale was comprised of seven items that were measured on a 5 -point scale ranging from 1 (strongly agree) to 5 (strongly disagree). Items include, "It is hard for young Black people to get ahead because they face so much discrimination," "Generally, I feel like a full and equal citizen in this country with all the rights and protections that other people have," and "On average, Black youth receive a poorer education than white youth." Again, all items were reverse coded such that a higher response indicates stronger perceptions of institutional discrimination $(\alpha=.70)$.

Political efficacy. Political efficacy assessed personal ability to problem-solve and handle unexpected events, particularly in regard to politics and social change. These four items were assessed on a 4-point Likert scale from 1 (strongly agree) to 4 (strongly disagree). All items were reverse coded such that higher responses indicate more efficacious beliefs. Items include, "I believe that by participating in politics I can make a difference," and "I have the skills and knowledge necessary to participate in politics," $(\alpha=.57)$.

Maternal education. Maternal education served as a proxy for socioeconomic status. Participants were asked, "What is the highest level of schooling your mother (or the person who has acted as a mother to you) completed?" Participants indicated maternal education on a 9-point ordinal scale from 1 (no school) to 9 (professional or graduate school). The majority of students' maternal figure had a high school $(35.3 \%)$ or college $(24.1 \%)$ education.

Civic education. To assess civic education, participants indicated whether they had taken a high school American government or civics course. Responses were coded such that yes $=1$ and no $=0$.

Civic engagement. To assess civic engagement, each participant indicated whether or not they had participated in each of 13 civic and political activities within the 12 months prior to survey administration. We then created a composite score of all of the civic engagement activities completed by each 
participant. Sample activities include the following: volunteer community work, campaigning, boycotting, protesting, participating in a political group, and participating in a political discussion. The majority of youth participated in zero $(14.7 \%)$, one $(21.4 \%)$, or two $(25.1 \%)$ civic activities. Approximately $4.4 \%$ of youth completed seven or more civic activities within the past year, with two participants completing 10 out of 13 activities. See Table 1 for a complete data on youth civic engagement.

\section{Data Analysis Plan}

We first conducted preliminary analyses to investigate bivariate relationships among our study variables. Next, we conducted hierarchical regression analyses to test whether sociopolitical attitudes relate to civic engagement and whether that relationship was moderated by civic education. Significant interaction effects were tested using simple slopes analyses as outlined by Aiken and West (1991).

\section{RESULTS}

\section{Preliminary Analysis}

We examined the means and standard deviations for all demographic and study variables and the relationship of the study variables through bivariate correlations (see Table 2). Political cynicism was positively related to perceived institutional discrimination and negatively related to political efficacy. Perceptions of institutional discrimination was positively associated with civic engagement. Similarly, political efficacy and civic education were both positively related to civic engagement. Maternal education had a low and positive relationship to civic education and civic engagement.

Next, we examined mean group differences by gender, civic education, and age. Regarding age, a dichotomous variable was created to reflect participants 15-17 years old and those 18-25 years old. Preliminary analyses revealed mean group differences in civic education by gender, $t(591)=2.09$, $p<.05$. More women indicated they had high school civic education $(M=.62, S D=.54)$ than did men $(M=.54, S D=.50)$. We also found mean group differences by civic education in civic engagement, $t(591)=-4.27, p<.001$. Participants who had completed a high school civic course participated in more civic activities $(M=2.69$, $S D=2.08)$ than those who had not $(M=2.00$, $S D=1.69)$. Finally, we tested mean group differences among adolescent (15-17) and young adult participants (18-25). We found significant differences in civic education $t(591)=-2.90, p<.01$, political cynicism $t(591)=-4.37, p<.001$, perceived institutional discrimination $t(591)=-4.05$, $p<.001$, and civic engagement $t(591)=2.93$, $p<.01$. More young adults had completed a civic education course $(M=.63, S D=.48)$ than had adolescents $(M=.50, S D=.50)$. With regard to political attitudes, young adults were more cynical $(M=2.38, S D=.52)$ and held greater perceptions of systemic inequalities $(M=3.22, S D=.70)$ than adolescents $\quad(M=2.19, \quad S D=.44 ; \quad M=2.98$, $S D=.67)$. Finally, adolescents participated in more civic activities $(M=2.73, S D=2.24)$ than young adults $(M=1.89, S D=1.97)$. Despite these differences, patterns of relationships did not vary substantially based on demographic variables (age, maternal, education, or gender).

TABLE 1

Percentage of Black Youth Who Participated in Civic Activities in the Past Twelve Months

\begin{tabular}{|c|c|c|c|}
\hline & Total Sample (\%) & Adolescents (\%) & Young Adults (\%) \\
\hline Contacted a public official & 7.9 & 5.9 & 9.0 \\
\hline Signed a petition & 16.5 & 15.3 & 17.3 \\
\hline Attended protest, demonstration, or sit-in & 8.3 & 9.4 & 7.7 \\
\hline Participated in a boycott & 2.9 & 3.0 & 2.8 \\
\hline Engaged in boycotting & 23.1 & 25.1 & 22.1 \\
\hline Joined or was active in a political group & 8.9 & 11.8 & 7.5 \\
\hline Wrote or sent an email/blog about a political issue & 17.4 & 25.6 & 13.1 \\
\hline Gave money to a political candidate, party, or issue & 9.8 & 13.3 & 8.0 \\
\hline Worked on a political campaign & 7.9 & 8.9 & 7.4 \\
\hline Talked with family or friends about a political issue, party, or campaign & 69.3 & 68.0 & 70.0 \\
\hline Worked with people in neighborhood on a political issue & 13.2 & 15.3 & 12.1 \\
\hline Wrote an article or letter to the editor about a political issue or problem & 5.2 & 11.3 & 2.1 \\
\hline Engaged in organized volunteer or community service work & 50.1 & 60.1 & 45.0 \\
\hline
\end{tabular}


TABLE 2

Means, Standard Deviations, and Pearson Correlations of Study Variables

\begin{tabular}{|c|c|c|c|c|c|c|c|c|}
\hline & 1 & 2 & 3 & 4 & 5 & 6 & 7 & 8 \\
\hline 1. Age & - & & & & & & & \\
\hline 2. Gender & $-.11^{*}$ & - & & & & & & \\
\hline 3. Maternal education & -.07 & -.02 & - & & & & & \\
\hline 4. Political cynicism & $.18^{* * *}$ & .04 & .02 & - & & & & \\
\hline 5. Systemic discrimination & $.19^{* * *}$ & -.02 & .02 & $.54^{* * *}$ & - & & & \\
\hline 6. Political efficacy & .04 & -.02 & .04 & $-.19^{* * *}$ & -.02 & - & & \\
\hline 7. Civic education & .05 & $-.09^{*}$ & $.12^{* *}$ & .01 & .03 & .07 & - & \\
\hline 8. Civic engagement & $-.12^{* *}$ & .02 & $.13^{* * *}$ & -.01 & $.12^{* *}$ & $.19^{* * *}$ & $.17^{* * *}$ & - \\
\hline$M$ & 19.24 & .44 & 5.95 & 2.31 & 3.14 & 3.07 & .58 & 2.40 \\
\hline$S D$ & 3.12 & .50 & 1.82 & .50 & .70 & .40 & .49 & 1.96 \\
\hline
\end{tabular}

Note. $N=542$.

${ }^{*} p<.05 ; * * p<.01 ; * * * p .001$.

\section{Sociopolitical Attitudes, Civic Education, and Civic Engagement}

We conducted hierarchical regression analysis to test whether political cynicism, perceptions of institutional discrimination, political efficacy, and civic education relate to civic engagement. To test these main effects, we entered each predictor variable into the first block of the regression model including age, gender, and maternal education as control variables. The model was significant, $F(7,585)=$ $10.68, p<.001$, and accounted for $11.3 \%$ of the variance in civic engagement (see Table 3). As expected, political efficacy was positively associated with civic engagement; the more youth believed they could positively impact political systems, the more civic engagement activities they reported. In addition, perceived institutional discrimination and civic education were significantly and positively related to civic engagement. The greater the awareness of institutional racial discrimination and having taken a civics course in high school contributed to higher levels of civic engagement. Political cynicism, however, was not associated with civic engagement.

\section{Civic Education as a Moderator}

Next, we tested whether civic education moderated the relationships between sociopolitical attitudes and civic education in the second step of the hierarchical regression analyses. After testing the main effects, we centered our continuous variables of interest and created interaction terms for political cynicism and civic education $(\mathrm{PC} \times \mathrm{CE})$, perceived institutional discrimination (PID $\times \mathrm{CE}$ ), and political efficacy and civic education $(\mathrm{PE} \times \mathrm{CE})$. We
TABLE 3

Summary of Hierarchical Regression Analysis Predicting Civic Engagement (CE)

\begin{tabular}{lccrr}
\hline & \multicolumn{4}{c}{ Model 1 } \\
\cline { 2 - 5 } & $\Delta R^{2}$ & $B$ & $S E$ & $\beta$ \\
\hline Step 1 & .113 & & & \\
Age & & $-0.10^{* * *}$ & 0.03 & -0.15 \\
Gender & 0.07 & 0.16 & 0.02 \\
Maternal education & & $0.10^{*}$ & 0.04 & 0.09 \\
Political cynicism (PC) & & -0.19 & 0.19 & -0.05 \\
Perceived institutional & & $0.48^{* * *}$ & 0.13 & 0.17 \\
discrimination (PID) & & & & \\
Political efficacy (PE) & & $0.86^{* * *}$ & 0.20 & 0.18 \\
Civic education & & $0.62^{* * *}$ & 0.16 & 0.16 \\
Step 2 & .005 & & & \\
PC $\times$ CE & & 0.03 & 0.37 & 0.01 \\
PID $\times$ CE & & 0.17 & 0.27 & 0.05 \\
PE $\times$ CE & & 0.60 & 0.39 & 0.09 \\
\hline
\end{tabular}

Note. $N=593$.

$* p<.05 ;{ }^{* * *} p<.001$.

tested the regression model and interactions using procedures outlined by Aiken and West (1991). The overall model was significant, $F(10,582))=7.77$, $p<.001$; however, the change in $R^{2}$ was $<1 \%$. We did not find support for our critical social analysis hypothesis, as there were no significant interaction between political cynicism and civic education or perceived institutional discrimination and civic education. The interaction between political efficacy and civic education did trend toward marginal significance $(\beta=.09, S E=.39, p=.13)$. Simple slopes analysis indicated that political efficacy was significantly associated with civic engagement for Black youth with civic education $(b=1.134, t=4.381$, $p<.001$ ), but only marginally for those with no 


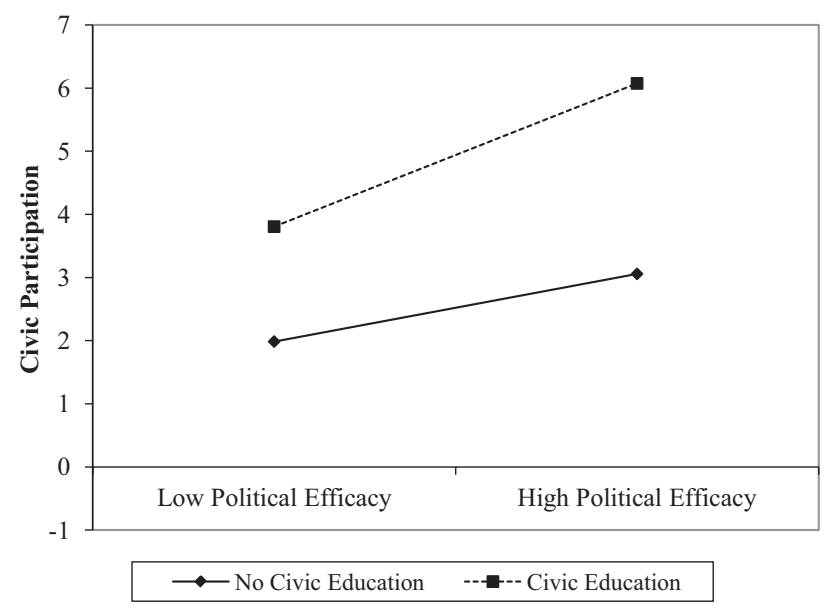

FIGURE 2 Relationship between civic participation and political efficacy by civic education.

formal civic education $(b=.536, t=1.849, p<.10)$ (Figure 2).

\section{DISCUSSION}

In the current study, we used data from the Black Youth Project (Cohen, 2005) to examine associations between sociopolitical attitudes, civic education, and civic engagement among Black youth, in contribution to the growing scholarly literature in this area. Given literature that suggests substantial variety in the ways that Black youth participate as political citizens, we first considered civic engagement broadly.

With regard to associated sociopolitical attitudes, we found some evidence to support the assumption that critical analysis of sociopolitical systems and government institutions is related to civic engagement. This finding supports the SPD model's contention that critical analysis of oppressive institutional structures may be related to civic and political action toward social change. The current findings show that youth who adhere to beliefs in institutional discrimination participated in more civic engagement activities. However, political cynicism was not significantly related to civic engagement for Black youth. Black youth engage more civically and politically when they have a broad, structural understanding of why inequities exist, not just a belief that the system is unfair and the government is biased against them. This finding supports research that suggests that Black youth may be more prepared to participate in political systems when they acknowledge and confront social and political inequity (Ginwright, 2010a,b; Stevenson, McNeil, Herrero-Taylor, \& Davis, 2005).
Ginwright (2010b) asserts that when youth are prepared to interrogate injustice and inequality, they also are better prepared to enact system change through public policy and legislation.

Our findings also suggest the importance of civic education in relation to civic engagement. Youth who reported taking a civics course during high school were involved in more civic and political activities, ranging from voluntary community service work, political discussions and campaigning, to boycotting. This is promising, as it suggests that mere presence of civic education has a positive association with civic engagement. However, it is noteworthy that approximately $40 \%$ of our sample reported not receiving any civics education. According to the Center for Information and Research on Civic Learning \& Engagement (CIRCLE), all 50 states and the District of Columbia have social studies standards than include topics of power, authority, and government, but only 42 have a standard of real-world application and only nine states have an assessment requirement (Godsay et al., 2012). While 48 states (as well as the District of Columbia) have a social studies requirement for graduation, only 40 states specify that an American government or civics course fulfill that requirement. Given the emphasis on literacy and math in standardized tests, social studies have been demoted with regard to curricular decisions; however, it is clear from this work that lack of civic education is meaningful contributor to decreases in civic engagement among Black youth.

Further, we replicated findings that political efficacy is related to civic engagement among Black youth. As suggested by social cognitive theory and empowerment literatures (Zimmerman, 1995), Black youth who had stronger beliefs in their own capacity to participate in politics and effect change also were more civically engaged. To extend such work, we also found that civic education bolstered the impact of political efficacy on civic engagement. Again, we find that civic education is an important factor related to civic engagement. This evidence further suggests that civic education should be considered more broadly and centrally when examining causes and correlates of civic engagement, particularly among Black youth. Not only is civic education directly associated with civic engagement, but civic education helps to foster political efficacy in support of civic engagement among Black youth.

Our findings also reveal more about the nature of civic and political activities that Black youth 
engage in throughout adolescence and young adulthood. Among our sample, only $15 \%$ of participants had no civic or political engagement within 12 months prior to survey administration and over $4 \%$ of youth had completed at least half of all possible civic activities that were probed. This finding is encouraging, as this indicates a high rate of civic participation and political interest among Black youth. Even more, there was considerable variation in the types of civic engagement that Black youth pursued. The most popular mode of civic engagement was talking with family and friends about politics, with over $69 \%$ of all participants engaged in that activity. Similarly, half of the participants had participated in volunteer community service work. Other frequent modes of civic engagement included petitioning and blogging or emailing about political issues. Most notably, almost a fourth of all Black youth in this study had engaged in boycotting. Boycotting is an economic boycott against companies and products that do not align with one's social or political values. Thus, a substantial amount of Black youth are asserting monetized social and political control and voicing political opinion through fiscal decision making.

There were also differences in civic engagement between adolescents (15-17 years old) and young adults (18-25 years old). Overall, adolescents participated in more civic activities than young adults did. This was surprising, given that young adults have more autonomy over their time and can make active decisions to participate, where adolescents may need parent consent or facilitated opportunities to participate. One of the most surprising findings was that adolescents protested and engaged in boycotts more than young adults. Young adults, on the other hand, contacted public officials more than adolescents. Our work shows that even prior to the age of voting eligibility adolescents are interested in and engaging sociopolitical systems. These findings support the growing body of research that is investigating early predictors of civic engagement, beginning in childhood and early adolescents. These scholars suggest that one particularly important developmental transition period for civic development is during early adolescence-generally between the end of elementary school and the beginning of high school, between the ages of 10 and 14 years old (Eckstein, Noack, \& Gniewosz, 2012; Mitra \& Serriere, 2012).

Taken together, this work builds on current civic engagement and sociopolitical development literatures, providing insight to further understand psychological mechanisms that support civic and political development among Black youth. We consider this study a preliminary step in explicitly testing theoretical assumptions of the sociopolitical development model. As scholars have noted, given the modern and historical sociopolitical disenfranchisement experienced in the Black community, there may be a unique set of psychological mechanisms of action that help promote civic engagement among Black youth. As such, this study contributes to the literature by considering sociopolitical attitudes and civic education in relation to civic engagement among a nationally representative sample.

\section{Limitations and Future Directions}

We note several study considerations and directions for future work. This study employed survey data from a national probability sample for a political science-oriented study. This enhanced the generalizability of our findings, but also limited us with regard to issues of measurement from the perspective of psychological research. For example, our measures of political cynicism and political efficacy had moderate levels of internal consistency, which can be considered problematic for statistical tests. However, some research has suggested that moderate inter-item correlations are statistically appropriate, particularly when the items included in the measure are theoretically meaningful (Clark \& Watson, 1995). Despite moderately strong measures of sociopolitical attitudes, our findings were both significant and theoretically meaningful, and should only be strengthened by subsequent refinements in our measurement strategy.

Also, we were limited to a single-item indicator of civic education. However, our findings suggest that civic education is a meaningful factor related to civic engagement, and thus it is important to further understand the content of such civic courses as well as the classroom environment through which instruction takes place. More needs to be known about the quantity and quality of such educational opportunities. A substantial number of participants in this study reported not receiving a civic education, which calls into question the availability and quality of the civics education afforded to Black youth. This area of inquiry would be greatly strengthened by scholarly collaborations among educators, psychologists, and political scientists to investigate content, delivery, and 
effectiveness of civic education. Finally, in this study, we considered civic engagement as a unidimensional construct. Recently, scholars have suggested a typology of civic engagement that proposes civic and social engagement, formal political participation, and extra-parliamentary and activist engagement as separate dimensions (Ekman \& Amna, 2012). Given the range of sociopolitical activities that Black youth reported, it may be useful to understand if the psychological processes that relate to civic engagement broadly hold true when considering specific types of civic engagement. Conceptually, researchers should consider how to measure critical social analysis more broadly, particularly among adolescents. In the current study, we captured political cynicism and institutional discrimination as two important dimensions of critical analysis, but future studies should further complicate the meaning and indication of critical analysis.

We chose to control for age in our analyses, but recommend that future work specifically consider civic engagement processes among younger adolescents. In our work, young adults were more cynical than adolescents, and adolescents engaged more civically. This finding is consistent with some work that suggests that adolescents of color may become more cynical over time and that increased political distrust and skepticism may be the result of negative experiences attributed to failures of social and political authorities, such as insufficient public education (Fine, Burns, Payne, \& Torre, 2004). While our sample was limited to cross-sectional analysis, the potential for increased cynicism to relate to decreased participation provides evidence to support increased use of longitudinal methodology to examine civic development, including critical analysis as early as late childhood through adulthood.

Despite these limitations, the present study highlights civic engagement among Black youth and psychological mechanisms of action, such as political efficacy and perceived institutional discrimination that support civic and political engagement among Black adolescents and young adulthood. Our findings suggest that Black youth are highly involved in multiple types of civic engagement, and that civic education, political efficacy, and critical analysis support that involvement. As we continue to understand how Black youth engage in society, it is important to consider the broad range of civic beliefs and behavior that youth experience and how that may impact their actions as a citizen.

\section{REFERENCES}

Aiken, L., \& West, S. (1991). Multiple regression: Testing and interpreting interactions. Newbury Park, CA: Sage.

American Political Science Association (APSA) Task Force on Inequality and American Democracy. (2004). American democracy in an age of rising inequality. Perspectives on Politics, 2, 651-689. doi:10.1017/ S153759270404040X

Beaumont, E. (2010). Political agency and empowerment: Pathways for developing a sense of political efficacy in young adults. In. L. Sherrod, J. Torney-Purta, \& C. Flanagan (Eds.), Handbook of research on civic engagement in youth (pp. 525-558). Hoboken, NJ: John Wiley.

Bonilla-Silva, E. (1997). Rethinking racism: Towards a structural interpretation. American Sociological Review, 62, 465-480. doi:10.2307/2657316

Checkoway, B., Allison, T., \& Montoya, C. (2005). Youth participation in public policy at the municipal level. Children and Youth Services Review, 27, 1149-1162. doi:10.1016/j.childyouth.2005.01.001

Christens, B. (2012). Targeting empowerment in community development: A community psychology approach to enhancing local power and well-being. Community Development Journal, 47, 538-554. doi:10.1093/cdj/ bss031

Clark, L., \& Watson, D. (1995). Constructing validity: Basic issues in objective scale development. Psychological Assessment, 7, 309-319. doi:10.1037/1040-3590.7.3.309

Cohen, C. (2005). Black youth culture survey. Chicago, IL: Black Youth Project. Retrieved April 13, 2010, 2009 from http:/ / www.blackyouthproject.com

Dassonneville, R., Quintelier, E., Hooghe, M., \& Claes, E. (2012). The relation between civic education and political attitudes and behavior: A two-year panel study among Belgian late adolescents. Journal of Human Behavior and the Social Environment, 16, 140-150. doi:10. 1080/10888691.2012.695265

Diemer, M., \& Li, C. (2011). Critical consciousness development and political participation among marginalized youth. Child Development, 82, 1815-1833. doi:10.1111/j. 1467-8624.2011.01650.x

Eckstein, K., Noack, P., \& Gniewosz, B. (2012). Attitudes toward politial engagement and willingness to participate in politics: Trajectories throughout adolescence. Journal of Adolescence, 35, 485-495. doi:10.1016/j.adolescence.2011.07.002

Ekman, J., \& Amna, E. (2012). Political participation and civic engagement: Towards a new typology. Human Affairs, 22, 2-29. doi:10.2478/s13374-012-0024-1

File, T. (2013). The diversifying electorate: Voting rates by race and Hispanic origin in 2012 (and other recent elections). Current Population Survey Reports (pp. 20569). Washington, DC: U.S. Census Bureau.

Fine, M., Burns, A., Payne, Y., \& Torre, M. (2004). Civic lessons: The color and class of betrayal. Teachers College Record, 106, 2193-2223.

Finlay, A. K., Wray-Lake, L., \& Flanagan, C. A. (2010). Civic engagement during the transition to adulthood: 
Developmental opportunities and social policies at a critical juncture. In L. R. Sherrod \& J. Torney-Purta (Eds.), Handbook of research on civic engagement in youth (pp. 277-305). Hoboken, NJ: John Wiley.

Flanagan, C., \& Gallay, L. (2008). Adolescent development of trust (CIRCLE working paper 61). College Park, MD: Center for Information and Research on Civic Learning and Engagement.

Freire, P. (2005). Freire: Education for critical consciousness. New York, NY: Continuum.

Ginwright, S. (2010a). Black youth rising: Activism and radical healing in urban America. New York, NY: Teachers College Press.

Ginwright, S. (2010b). Peace out to revolution! Activism among African American youth: An argument for radical healing. Young: Nordic Journal for Youth Research, 18, 77-96. doi:10.1177/110330880901800106

Godsay, S., Henderson, W., Levine, P., \& LittenbergTobias, J. (2012). State of civic education requirements. Medford, MA: Center for Information and Research on Civic Learning and Engagement.

Hart, D., Donnelly, T., Youniss, J., \& Atkins, R. (2007). High school community service as a predictor of adult voting and volunteering. American Educational Research Journal, 44, 197-219. doi:10.3102/00028312062 98173

Hart, D., \& Gullan, R. (2010). The sources of adolescent activism: Historical and contemporary findings. In. L. Sherrod, J. Torney-Purta, \& C. Flanagan (Eds.), Handbook of research on civic engagement in youth (pp. 67-90). Hoboken, NJ: John Wiley.

Kahne, J., \& Middaugh, E. (2008). Democracy for some: The civic opportunity gap in high school (Working paper 59). College Park, MD: Center for Information and Research on Civic Learning and Engagement.

Lerner, R. (2004). Liberty: Thriving and civic engagement among America's youth. Thousand Oaks, CA: Sage Publications.

Levinson, M. (2007). The civic achievement gap (CIRCLE working paper 51). College Park, MD: Center for Information and Research on Civic Learning and Engagement.

Levinson, M. (2012). No citizen left behind. Cambridge, MA: Harvard University Press.

McGuire, J., \& Gamble, W. (2006). Community service for youth: The value of psychological engagement over number of hours spent. Journal of Adolescence, 29, 289298. doi:10.1016/j.adolescence.2005.07.006

Mitra, D., \& Serriere, S. (2012). Student voice in elementary school reform: Examining youth development in fifth graders. American Educational Research Journal, 49, 743-774. doi:10.3102/0002831212443079

Mohiyeddini, C., \& Montada, L. (1998). BJW and selfefficacy in coping with observed victimization: Results from a study about unemployment. In. L. Montada, \& M. Lerner (Eds.), Responses to victimizations and belief in a just world (pp. 41-54). New York, NY: Plenum Press.
National Center for Education Statistics (NCES). (2011). The nation's report card: Civics 2010 (NCES 2011-466). Washington, DC: NCES.

Reinders, H., \& Youniss, J. (2006). School-based required community service and civic development in adolescents. Applied Developmental Science, 10, 2-12. doi:10. 1207/s1532480xads1001_1

Rosenbloom, S., \& Way, N. (2004). Experiences of discrimination among African American, Asian American, and Latino adolescents in an urban high school. Youth and Society, 35, 420-451. doi:10.1177/0044118X03261479

Rubin, B. (2007). "There's still not justice": Youth civic identity development amid distinct school and community contexts. Teachers College Record, 109, 449-481.

Schmid, C. (2012). The value of "social responsibility" as a motivating factor for adolescents' readiness to participate in different types of political actions, and its socialization in parent and peer contexts. Journal of Adolescence, 35, 533-547. doi:10.1016/j.adolescence.2012. 03.009

Seaton, E., \& Yip, T. (2009). School and neighborhood contexts, perceptions of racial discrimination, and psychological well-being among African American adolescents. Journal of Youth and Adolescence, 38, 153-163. doi:10.1007/s10964-008-9356-X

Sellers, S., Bonham, V., Neighbors, H., \& Amell, J. (2006). Effects of racial discrimination and health behaviors on mental and physical health of middle-class African American men. Health Education and Behavior, 36, 3144. doi:10.1177/1090198106293526

Sherrod, L., Torney-Puerta, J., \& Flanagan, C. (2010). Research on the development of citizenship: A field coming of age. In. L. Sherrod, J. Torney-Purta, \& C. Flanagan (Eds.), Handbook of research on civic engagement in youth (pp. 1-22). Hoboken, NJ: John Wiley.

Slater, J., Fain, S., \& Rossatto, C. (2002). Freirean legacy: Educating for social justice. New York, NY: Peter Lang.

Smetana, J., \& Metzger, A. (2005). Family and religious antecedents of civic involvement in middle class African American late adolescents. Journal of Human Behavior in the Social Environment, 2, 196-212. doi:10.1111/ j.1532-7795.2005.00099.x

Stevenson, H., McNeil, J., Herrero-Taylor, T., \& Davis, G. (2005). Influence of perceived neighborhood diversity and racism experience on the racial socialization of Black youth. Journal of Black Psychology, 31, 273-290. doi:10.1177/0095798405278453

Watts, R., Diemer, M., \& Voight, A. (2011). Critical consciousness: Current status and future directions. In C. A. Flanagan \& B. D. Christens (Eds.), Youth civic development: Work at the cutting edge. San Francisco, CA: Jossey-Bass.

Watts, R., \& Flanagan, C. (2007). Pushing the envelope on youth civic engagement: A developmental and liberation psychology perspective. Journal of Community Psychology, 35, 779-792. doi:10.1002/jcop.20178

Watts, R., \& Guessous, O. (2006). Sociopolitical development: The missing link in research and policy on ado- 
lescents. In S. Ginwright, P. Noguera, \& J. Cammarota (Eds.), Beyond resistance! Youth activism and community change: New democratic possibilities for practice and policy for America's youth. New York, NY: Routledge.

Watts, R., Williams, N. C., \& Jagers, R. (2003). Sociopolitical development. American Journal of Community Psychology, 31, 185-194. doi:10.1023/A:1023091024140

White-Johnson, R. (2012). Prosocial involvement among African American young adults: Considering racial discrimination and racial identity. Journal of Black Psychology, 38, 313-341. doi:10.1177/0095798411420429

Yates, M., \& Youniss, J. (1996). A developmental perspective on community service in adolescents. Social Development, 5, 85-111. doi:10.1111/j.1467-9507.1996.tb00073. $x$

Zimmerman, M. A. (1995). Psychological empowerment: Issues and illustrations. American Journal of Community Psychology, 23, 581-600. doi:10.1007/BF02506983 